\title{
Cultivating Students' Professional Quality in Business Interpreting Course
}

\author{
Zhaoli Wu \\ Shandong Women's University \\ Jinan, Shandong, China
}

\begin{abstract}
There are numerous reasons contributing to the difficulty in job hunting for college graduates, and the deficiency in professional quality is among them. Therefore, if scholars can find the way to promote students' development in professional quality, the key will be found to reduce employment stress. This paper dedicates to explore how to cultivate students' professional quality in the course of Business English Interpreting.
\end{abstract}

Keywords-professional quality; interpreting teaching; specialized knowledge; specialized skill

\section{INTRODUCTION}

For the development of vocational college education, it's vital to give full consideration to professional qualities that students need in their future career, and center on promoting students' professional quality. In recent years, driven by employment stress, relevant departments in the government, Internet organizations and some colleges and universities have conducted a series of researches, which show that job positions are putting higher and higher requirements on college graduates who are finding employment. This phenomenon leads to the contradiction between the current situation of college education and the needs of job market. On one hand, some college students are deficient in professional quality so that they can find satisfied jobs; on the other hand, some employing units are setting higher and higher requirements on graduates that they can not find qualified employees. The key to cope with this contradiction is to carry out a suite of reforms in cultivation plans and education forms in colleges and universities, setting the goal of "cultivating qualified graduates with high professional quality, and meeting the needs of job market." Teaching objectives, teaching contents and teaching methods must be justified so that students will be fully prepared for future job.

\section{PROFESSIONAL QUALITY}

Scholars have different understandings on the notion of professional quality (PQ, for short). On one hand, PQ refers to the comprehensive quality that an employee shows in the process of conducting professional activities, including professional skill, professional ethics, working passion and so on. PQ is the overall performance of a person in his/her career.

In this paper, the research was sponsored by the Shandong Business and Administration Project. (Project No. J201527)
PQ can be identified as high or low, because every person performs differently in their job. On the other hand, PQ can be described as the inner rules and requirements within a certain profession. In other words, PQ is some specific qualities that a person must have or certain codes of conduct that a person must comply with while he/she is engaged in a certain profession. The evaluation standard of PQ varys according to different professions. For example, some employing units pay much attention to "professional dedication", "working attitude", ect. and list them as important components of PQ. The higher one's PQ level is, the more popular he/she will become among employing units.

Nowadays, many domestic scholars have done research on PQ from different angles. Some scholars focus on the current cultivating situation and cultivating strategies, such as Wang Hongyan, who puts forward that the cultivation of PQ should be reflected in talent trainning mode and carried out in specialized course teaching[1]. Some scholars study the construction of cultivation system, such as Zhang Qiong, who advocates strengthening school-enterprise cooperation, creating various teaching situation and promoting interactions of student associations[2]. Some scholars anayze the cultivation of PQ in a certain profession such as Wang Yafeng, who explores the cultivation of PQ for IT majors and gives suggestions on how to make career plan[3]. To sum up, from the aspect of content, scholars have made comprehensive study on the notion, importance, and current situation of the cultivation of PQ; from the aspect of cultivating strategy, most of the scholars have studied how to cultivate students' PQ from the macro level. Comparatively speaking, there are few studies on the detailed implementation method to carry out PQ education. Taking Business Interpreting course as an example, this paper explores how to perform PQ education in daily teaching activities.

\section{PQ ANALYSIS FOR BUSINESS ENGLISH MAJORS}

Lu Ganglan holds that the connotation of PQ includes professional ethics, professional awareness, professional behavior and professional skill in academic community, while PQ is more specific in professional community, including cooperative quality, innovative quality, moral quality, specialized quality and so on[4]. According to the statement of "high quality and skilled talents", students' PQ includes two aspects, namely, specialized quality and non- 
specialized quality. "high quality" means high nonspecialized quality, such as passion and dedication, good sense of responsibilities, team spirit, etc., which belong to consciousness such as worldview, philosophy and values. Non-specialized quality is formed gradually in the long period of life, study and work. "skilled" means high specialized quality such as solid specialized knowledge, strong practical ability and innovation ability, etc.. Specialized quality is professional knowledge and skill which can be acquired through a period of learning or training. The connotation of PQ for business English majors is shown in the following table. "Table I"

TABLE I. THE CONNOTATION OF PQ FOR BUSINESS ENGLISH MAJORS

\begin{tabular}{|c|c|c|}
\hline \multirow[t]{3}{*}{$\begin{array}{l}\text { Non- } \\
\text { specialize } \\
\text { d Quality }\end{array}$} & $\begin{array}{c}\text { professional } \\
\text { ethics }\end{array}$ & $\begin{array}{l}\text { passion, devotion, seeking truth, obeying } \\
\text { laws, keeping secret, fairness and } \\
\text { transparency, etc. }\end{array}$ \\
\hline & $\begin{array}{c}\text { professional } \\
\text { awareness }\end{array}$ & $\begin{array}{l}\text { sense of integrity, team spirit, sense of } \\
\text { self-discipline, sense of learning, sense of } \\
\text { service, etc. }\end{array}$ \\
\hline & $\begin{array}{c}\text { professional } \\
\text { behavior }\end{array}$ & $\begin{array}{l}\text { being familiar with office process, giving } \\
\text { feedback of bottleneck and problem, } \\
\text { making work plan, obeying work } \\
\text { arrangement, etc. }\end{array}$ \\
\hline \multirow[t]{2}{*}{$\begin{array}{l}\text { Specialize } \\
\text { d Quality }\end{array}$} & $\begin{array}{l}\text { specialized } \\
\text { knowledge }\end{array}$ & $\begin{array}{l}\text { basic knowledge of business English } \\
\text { (business reception, business etiquette, } \\
\text { being a secretary concerning foreign } \\
\text { affairs), basic knowledge of computer, } \\
\text { cross-cultural knowledge, etc. }\end{array}$ \\
\hline & $\begin{array}{c}\text { specialized } \\
\text { skill }\end{array}$ & $\begin{array}{l}\text { integrated competence in language usage, } \\
\text { cross-cultural communicative competence, } \\
\text { learning ability, innovation ability, } \\
\text { communication skills, etc. }\end{array}$ \\
\hline
\end{tabular}

It is of great importance to make a full understanding of the connotation of PQ for business English majors, because it will help teachers to make clear the teaching objectives so that they can carry out the idea of cultivating PQ in every teaching procedure.

\section{CUltivating PQ IN BUSINESS INTERPRETING COURSE}

At present, there is a serious problem in business interpreting teaching that too much attention has been paid to the cultivation of specialized quality, while too little attention has been paid to the cultivation of non-specialized quality. In daily teaching activities, introduction to interpreting skills and practice of interpreting ability have taken up most of the students' time in and out of class, so that there is little time left for non-specialized quality cultivation, such as professional ethics, professional awareness, etc.. This phenomenon leads to a series of problems, such as being weak in professional ethics or professional awareness, lacking nice professional bahavior, etc., bringing negtive effect on students' competitive power. Bai Honghui believes that, such factors as the sense of obedience and devotion, the spirit of hard-working and team work, etc., belong to the connotation of PQ. While these fators are badly in need in employing units, they are difficult to find in college graduates[5].
The author conducted a research concerning "the current situation of non-professional quality cultivation for college students" in Shandong Women's University. 60 questionnaires are released to 60 business English majors who graduated in the year 2013, and 56 copies are collected, among which 53 copies are effective. After sorting and analyzing datas, $84.9 \%$ of the former graduates reflect that they lack the sense of self-discipline in their post; $75.4 \%$ of them reflect that their professional behavior needs to be improved; $96.2 \%$ of them suggest that non-specialized quality education should be added to college education. Therefore, non-specialized quality education is seriously inadequate in the teaching process of business English education at present. In fact, this reality contradicts with the requirements of job position, and results in graduates' bad performance in job hunting and incompetence in their job position.

Consequently, the present business English teaching mode cannot meet students' learning need and should be reformed. Since specialized quality and non-specialized quality are of equal importance, the phenomenon of "emphasizing on one side while ignoring the other side" should be removed. In daily teaching practice, nonspecialized quality education should be carried out in every class period and reflected in the teaching objectives, teaching contents, teaching procedures, teaching methods, and teaching evaluation. In the following part, the author describes how to conduct PQ cultivation from the above five aspects.

\section{A. The Setting of Teaching Objectives}

Up to now, most of the business English education in vocational colleges aims at improving students communication skills in English and strengthening students' cross-culture communicative competence, achieveing the goal of cultivating "practical talents" with good English proficiency who can independently conduct business activites, such as international trade, being a secretary concerning foreign affairs, etc... It is obvious that such statements as "communication skills in English", "crossculture communicative competence", and "being a secretary concerning foreign affairs" are all description about specialized quality education, and there is little description about non-specialized quality education in this sort of talent cultivating objectives. Under the guidance of such talent cultivation objectives, most of the courses offered to business English majors have ignore students' nonspecialized quality cultivation in the process of teaching. As far as business interpreting course is concerned, the setting of teaching objectives should be based on the understanding of the connotation of PQ for business English majors. Since specialized qualit and non-specialized qualit are of equal importance, two major teaching objectives should be classified, namely, specialized quality cultivation objectives and non-specialized quality cultivation objectives. For example, the teaching objectives setting of Unit 4 "Business Travel" in Business Interpreting (published by Foreign Language Teaching and Research Press) is shown in the following table. "Table II" 
TABLE II The TEACHING OBJECTIVES Setting OF UNIT 4 "BuSINESS TRAVEL" IN BUSINESS INTERPRETING

\begin{tabular}{|c|c|c|}
\hline \multirow{3}{*}{$\begin{array}{l}\text { Non- } \\
\text { specailized } \\
\text { Quality } \\
\text { Objectives }\end{array}$} & $\begin{array}{l}\text { Professional } \\
\text { ethics }\end{array}$ & $\begin{array}{l}\text { passion and devotion: the job of being a } \\
\text { secretary concerning foreign affairs. }\end{array}$ \\
\hline & $\begin{array}{c}\text { Professional } \\
\text { awareness }\end{array}$ & $\begin{array}{l}\text { team spirit, sense of self-discipline, sense of } \\
\text { learning, sense of service. }\end{array}$ \\
\hline & $\begin{array}{c}\text { Professional } \\
\text { behavior }\end{array}$ & $\begin{array}{l}\text { 1. factors and procedures of business travel } \\
\text { arrangement; } \\
\text { 2. habit of reporting bottleneck problem and } \\
\text { making work plan. }\end{array}$ \\
\hline \multirow[t]{2}{*}{$\begin{array}{l}\text { Specailize } \\
\text { d Quality } \\
\text { Objectives }\end{array}$} & $\begin{array}{l}\text { Specialized } \\
\text { knowledge }\end{array}$ & $\begin{array}{l}\text { 1. basic knowledge of business English: } \\
\text { expressions about business travel; } \\
2 \text {. knowledge of cross-culture } \\
\text { communication. }\end{array}$ \\
\hline & $\begin{array}{l}\text { specialized } \\
\text { skills }\end{array}$ & $\begin{array}{l}\text { 1. interpreting skills: Decoding Training } \\
\text { (II): Discourse Analysis; } \\
\text { 2. integrated competence in language usage: } \\
\text { listening, speaking, interpreting; } \\
\text { 3. other abilities: communicative ability, } \\
\text { cross-culture communication ability, } \\
\text { learning ability, etc.. }\end{array}$ \\
\hline
\end{tabular}

\section{B. The Choosing of Teaching Contents}

Teaching contents and teaching activities are the carrier of teaching objectives and aim at realizing teaching objectives. Therefore, the choosing of teaching contents depends on the teaching objectives setted, serves the realization of teaching objectives and impacts directly on the realization of teaching objectives. Only if proper teaching contents can be arranged, the origial teaching objectives can be achieved sucessfully. Concerning the choosing of teaching contents in business English interpreting course, the author holds that the following factors should be taken into consideration.

Firstly, the choosing of teaching contents should aim at job market, meeting the requirements of job position. As market is dynamic, requirements for job seeker's PQ are changing accordingly. Therefore, the teaching contents of every course should be adjusted and updated timely to meet the latest development of job market. Materials related to job position in real life should be added to teaching contents, such as case analysis concerning unit topic, current employment situation, etc... As classroom time is limited, teachers are not supposed to cover all the contents on the textbook, but focus on the most practical ones. Therefore, teachers are under more pressure now. They have to pay close attention to the latest development of the discipline, and follow the new changes in job market and position requirements timely.

Secondly, the choosing of teaching contents should center on students, meeting their realistic needs. Student is the subject of teaching activities, so teaching contents should suit students' learning needs and knowledge basis. On one hand, the difficulty level of teaching contents should be proper. Either too difficult or too easy teaching contents is good for the realization of teaching objectives. On the other hand, "student-oriented" means that students' ideas should be highly valued. It is advisable for teachers to organize a discussion on the topic of the unit before class, so that students' good opinions can be collected and adopted. In addition, regarding to the diversity of the teaching contents, teachers should aim at stimulating students' learning interest.
If teaching contents are rich and colorful, students may gain great pleasure while acquiring knowledge and skills.

Finally, the choosing of teaching contents should direct at the realization of teaching objectives, meeting the needs of PQ cultivation. Presently, most of the teaching contents of business interpreting course focus on the cultivation of specialized quality, such as language skills, interpreting skills, etc., ignoring the cultivation of non-specialized quality cultivation. Therefore, it is necessary for teachers to add nonspecialized quality contents to their classroom teaching process, such as teaching materials concerning professional ethics, professional awareness, professional behaviors, etc..

\section{The Designing of Teaching Procedures}

According to applied psychology, human's congnitive process includes four stages: perceiving, understanding, consolidating and applying. Based on this congnitive rule, many language teachers divide language teaching process into five stages: warming-up, reviewing, new contents teaching, consolidating and homework. Therefore, the teaching procedures of business interpreting course may follow these five steps. Under the guidiance of PQ cultivation teaching objectives, every teaching step should be well-designed so that cultivation activities can be carried out in and out of classroom. Take Unit 4 Business Travel as an example. "Table III"

TABLE III. The TEACHING PROCEDURES OF BUSINESS INTERPRETING COURSE

\begin{tabular}{|c|c|c|}
\hline $\begin{array}{c}\text { Teaching } \\
\text { Procedures }\end{array}$ & $\begin{array}{c}\text { Teaching Activities and Time } \\
\text { Arrange ment }\end{array}$ & Teaching Objectives \\
\hline $\begin{array}{l}\text { Warming- } \\
\text { up }\end{array}$ & $\begin{array}{l}\text { 1. students' presentation: } \\
\text { secretary concerning foreign } \\
\text { affairs }(10 \mathrm{~min}) \text {; } \\
\text { 2. evaluation }(5 \mathrm{~min}) \text {. }\end{array}$ & $\begin{array}{l}\text { learning about } \\
\text { concerning foretary } \\
\text { affair; } \\
\text { improving autonomous } \\
\text { learning awareness; } \\
\text { challenging business } \\
\text { presentation ability. }\end{array}$ \\
\hline Reviewing & $\begin{array}{l}\text { 1. Question \& Answer: Unit } 3 \\
\text { (5min); } \\
\text { 2. sentence interpreting ( } 5 \mathrm{~min}) \text {. }\end{array}$ & $\begin{array}{l}\text { integrated competence in } \\
\text { language usage: } \\
\text { listening, speaking and } \\
\text { interpreting. }\end{array}$ \\
\hline $\begin{array}{l}\text { New } \\
\text { Contents } \\
\text { Teaching }\end{array}$ & $\begin{array}{l}\text { 1. phrase interpreting }(5 \mathrm{~min}) \text {; } \\
\text { 2. passage interpreting: Text } \mathrm{C} \\
\text { (15min); } \\
\text { 3. conversation interpreting: } \\
\text { Text B (10min); } \\
\text { 4. interpreting skills (10min). }\end{array}$ & $\begin{array}{l}\text { words and expressions } \\
\text { about business travel; } \\
\text { arrangement of business } \\
\text { travel; interpreting skills: } \\
\text { discourse analysis. }\end{array}$ \\
\hline $\begin{array}{l}\text { Consolidati } \\
\text { ng }\end{array}$ & $\begin{array}{ll}\text { Supplementary } & \text { exercises: } \\
\text { Situation A }(12 \mathrm{~min}) & \end{array}$ & $\begin{array}{lr}\text { team } & \text { spirit, } \\
\text { communicative } & \text { ability, } \\
\text { etc.. } & \\
\end{array}$ \\
\hline Homework & $\begin{array}{l}\text { 1. Discussion: Culture Salon } \\
\text { (8min); } \\
\text { 2. Assignment: Talk on "Travel } \\
\text { Arrangements". }\end{array}$ & $\begin{array}{l}\text { arrangement of business } \\
\text { travel; } \\
\text { professional behavior: } \\
\text { making work plan, } \\
\text { report problem, etc.. }\end{array}$ \\
\hline
\end{tabular}

\section{The Adopting of Teaching Methods}

Teaching method is a general term for methods and means used by teachers and students to achieve common teaching objectives and accomplish common teaching tasks in the teaching process. Therefore, teaching methods not only refer to teacher's teaching method, but also refer to 
student's learning method. It is the unity of teaching methods and learning methods. The adopting of teaching method depends on the specific teaching objectives, different teaching contents and various students' characteristics of learning.

There a lot of teaching methods which are commonly used in the teaching processes of business English interpreting course, for example, lecturing method, demonstrating method, discussing method, exercising method, autonomous learning method, situation-creating method, task-driven method, and so force. In daily teaching and learning pratice, if these methods can be used properly and flexiblely, students' learning interest will be greatly motivated and sound teaching result will be achieved. Take the adoption of teaching methods in Unit 4 Business Travel as an example. "Table IV"

TABLE IV. The Adoption of TEACHING Methods IN Unit 4 BUSINESS TRAVEL

\begin{tabular}{|c|c|c|c|}
\hline $\begin{array}{c}\text { Teaching } \\
\text { Procedure } \\
\text { s }\end{array}$ & $\begin{array}{l}\text { Teaching } \\
\text { Activities }\end{array}$ & $\begin{array}{l}\text { Teaching } \\
\text { Objectives }\end{array}$ & Teaching Methods \\
\hline $\begin{array}{l}\text { Warming- } \\
\text { up }\end{array}$ & $\begin{array}{l}\text { student's } \\
\text { presentation; } \\
\text { 2. evaluation }\end{array}$ & $\begin{array}{l}\text { secretary } \\
\text { concerning } \\
\text { foreign affairs; } \\
\text { autonomous } \\
\text { learning ability; } \\
\text { business } \\
\text { presentation } \\
\text { ability. }\end{array}$ & $\begin{array}{l}\text { task-driven method; } \\
\text { discussing. }\end{array}$ \\
\hline Reviewing & $\begin{array}{l}\text { 1. Q \& A: Unit } 3 \\
\text { 2. sentence } \\
\text { interpreting }\end{array}$ & $\begin{array}{l}\text { integrated } \\
\text { competence in } \\
\text { language usage: } \\
\text { listening, } \\
\text { speaking and } \\
\text { interpreting. }\end{array}$ & $\begin{array}{l}\text { situation-creating } \\
\text { method. }\end{array}$ \\
\hline $\begin{array}{l}\text { New } \\
\text { contents } \\
\text { teaching }\end{array}$ & $\begin{array}{l}\text { phrase } \\
\text { interpreting } \\
\text { passage } \\
\text { interpreting } \\
\text { Conversation } \\
\text { interpreting } \\
\text { interpreting } \\
\text { skills }\end{array}$ & $\begin{array}{l}\text { expressions } \\
\text { about business } \\
\text { travel; } \\
\text { arrangement of } \\
\text { business travel; } \\
\text { interpreting } \\
\text { skill: discourse } \\
\text { analysis. }\end{array}$ & $\begin{array}{l}\text { lecturing; } \\
\text { exercising; } \\
\text { autonomous } \\
\text { learning; } \\
\text { situation-creating } \\
\text { method. }\end{array}$ \\
\hline $\begin{array}{l}\text { Consolidat } \\
\text { ing }\end{array}$ & $\begin{array}{l}\text { supplementary } \\
\text { exercises }\end{array}$ & $\begin{array}{l}\text { team spirit, } \\
\text { communicative } \\
\text { ability, etc.. }\end{array}$ & $\begin{array}{l}\text { task-driven method; } \\
\text { autonomous } \\
\text { learning. }\end{array}$ \\
\hline Homework & $\begin{array}{l}\text { discussion: } \\
\text { culture Salon } \\
\text { assignment; } \\
\text { free talk }\end{array}$ & $\begin{array}{l}\text { arrangement of } \\
\text { business travel; } \\
\text { professional } \\
\text { behavior: } \\
\text { making work } \\
\text { plan, reporting } \\
\text { problem, etc.. }\end{array}$ & $\begin{array}{l}\text { discussing; } \\
\text { task-driven method; } \\
\text { autonomous } \\
\text { learning. }\end{array}$ \\
\hline
\end{tabular}

\section{E. The Arranging of Teaching Evaluations}

Teaching evaluation is the measurement of teaching process and teaching effect, including the assessment of the teacher's teaching quality and student's learning result. Teaching evaluating is a supervision of teaching and learning, through which every aspect of teaching and learning can be seen. In the process of evaluating, students' knowledge, skills, intelligence and moral can get improved. Therefore, arranging scientific evaluating standard and conducting effective evaluation are of great importance. The evaluation of PQ cultivation-oriented business interpreting course is made up of two parts: the evaluation of teacher and the evaluation of students. As far as students' evaluation is concerned, it includes the assessment of students' specialized quality and the assessment of students' non-specialized quality. Such factors as professional awareness, professional behaviors should be take into consideration.

\section{CONCLUSION}

The trend of employment-oriented is the development derection of vocational education. Cutivating students' $P Q$ is one of the major tasks of colleges and universities. The cultivation of students' PQ should be implemented in daily teaching process and reflected in teaching objectives, teaching contents, teaching procedures, teaching methods and teaching evaluations. Obviously, the cultivation of students' PQ is a complex and difficult task. Therefore, the only effort of colleges' and universities' is far from enough, so that colleges, family and society are supposed to join hands to make great improvement in the current situation of PQ cultivaton.

\section{ACKNOWLEDGMENT}

Wu Zhaoli thanks all her colleagues in the research group and all friends who gave her help in the process of research and thesis writing.

\section{REFERENCES}

[1] Wang Hongyan. Cultivation Strategies of Professional Quality for Vocational College Students [J]. Hei Longiiang Higher Education Research, 2012(02):130-132.

[2] Zhang Qiong. Construction and Implement of Professional Quality Cultivation System for Vocational College Students [J]. China Adult Education, 2012 (21): 102-104

[3] Wang Yafeng. On Requirements for Professional Quality of Vocational College IT Majors from the Perspective of Emplyee Standards of Chinese and Foreign Enterprise [J]. Consume Guide, 2008(22):162-164.

[4] Lu Ganglan. On Cultivation of Professional Quality for Vocational College Students [J]. China Adult Education, 2008 (12): 111-112.

[5] Bai Honghui. Strengthening the Cultivation of Professional Quality for Vocational College Students [J]. Journal of Changsha Aeronautical Vocational and Technical College. 